\title{
Fictional metaphysics of fiction: Metaphysics and imagination in the humanities
}

\begin{tabular}{|c|c|}
\hline $\begin{array}{l}\text { Author: } \\
\text { Johann-Albre }\end{array}$ & Meylahn¹ \\
\hline $\begin{array}{l}\text { Affiliation: } \\
\text { 'Department } \\
\text { Theology, Fac } \\
\text { Theology, Un } \\
\text { Pretoria, Sou }\end{array}$ & $\begin{array}{l}\text { Practical } \\
\text { lity of } \\
\text { ersity of } \\
\text { Africa }\end{array}$ \\
\hline $\begin{array}{l}\text { Research Proj } \\
\text { Project Leade } \\
\text { Project Numb }\end{array}$ & $\begin{array}{l}\text { ct Registration: } \\
\text { : J.A. Meylahn } \\
\text { er: } 02187133\end{array}$ \\
\hline $\begin{array}{l}\text { Description: } \\
\text { This research } \\
\text { project, 'Towe } \\
\text { postfoundatic } \\
\text { public theolog } \\
\text { to the challen } \\
\text { religion in cor } \\
\text { Southern Afri } \\
\text { Prof. Dr Johan } \\
\text { Department F } \\
\text { Theology, Fac } \\
\text { Theology, Uni } \\
\text { Pretoria. }\end{array}$ & $\begin{array}{l}\text { s part of the } \\
\text { rds a practical } \\
\text { nal theology as } \\
\text { y in response } \\
\text { ses of lived } \\
\text { temporary } \\
\text { a', directed by } \\
\text { Meylahn, } \\
\text { actical } \\
\text { Ilty of } \\
\text { ersity of }\end{array}$ \\
\hline $\begin{array}{l}\text { Correspondin } \\
\text { Johann-Albre } \\
\text { johann.meyla }\end{array}$ & $\begin{array}{l}\text { author: } \\
\text { ht Meylahn, } \\
\text { in@up.ac.za }\end{array}$ \\
\hline $\begin{array}{l}\text { Dates: } \\
\text { Received: } 09 \text { J } \\
\text { Accepted: } 04 \\
\text { Published: } 25\end{array}$ & $\begin{array}{l}\text { une } 2017 \\
\text { ept. } 2017 \\
\text { Oct. } 2017\end{array}$ \\
\hline $\begin{array}{l}\text { How to cite th } \\
\text { Meylahn, J-A., } \\
\text { 'Fictional met } \\
\text { fiction: Metap } \\
\text { imagination in } \\
\text { humanities', } \\
\text { Studies/Theol } \\
73(3) \text {, a4699. } \\
\text { 10.4102/hts.v }\end{array}$ & $\begin{array}{l}\text { is article: } \\
2017, \\
\text { physics of } \\
\text { hysics and } \\
\text { the } \\
\text { TS Teologiese } \\
\text { gical Studies } \\
\text { tttps://doi.org/ } \\
73 \text { i3.4699 }\end{array}$ \\
\hline $\begin{array}{l}\text { Copyright: } \\
\text { @ 2017. The } \\
\text { Licensee: AOS } \\
\text { is licensed un } \\
\text { Creative Comr } \\
\text { Attribution Lic }\end{array}$ & $\begin{array}{l}\text { uthors. } \\
\text { S. This work } \\
\text { ler the } \\
\text { nons } \\
\text { ense. }\end{array}$ \\
\hline Read online: & \\
\hline 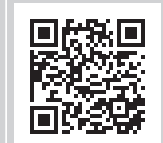 & $\begin{array}{l}\text { Scan this QR } \\
\text { code with your } \\
\text { smart phone or } \\
\text { mobile device } \\
\text { to read online. }\end{array}$ \\
\hline
\end{tabular}

Author:

Affiliation

${ }^{1}$ Department of Practical

Theology, Faculty of

Theology, University of

Project Leader: J.A. Meylahn

Project Number: 02187133

Description

postfoundational theology as public theology in response

to the challenges of lived religion in contemporary Prof. Dr Johann Meylahn,

Department Practical

Theology, Faculty of

Theology, University of

Corresponding author: Johann-Albrecht Meylahn,

Dates:

Accepted: 04 Sept. 2017

fiction: Metaphysics and

imagination in the

humanities', HTS Teologiese

73(3), a4699. https://doi.org/

10.4102/hts.v73i3.4699

Copyright:

Licensee: AOSIS. This work

is licensed under the

Creative Commons

Attribution License.

mobile device

to read onlin
A very simplified description of physics could be, according to Wikipedia, natural science that involves the study of matter and its motion and behaviour through space and time. In relation to this simplified description of physics, metaphysics would then be that which gives matter, or metaphysics would be the reflection on the space and time in which matter is given. Yet, how are space and time connected? It is in language, or more specifically narrative (fiction), that space and time are connected or brought together - language, as the time-space-play in which matter and its motion and behaviour is revealed or created. One could argue that what I have just written is then also a narrative in which physics and metaphysics are given in a specific space and time, the space and time of this article. Thus, one could argue that metaphysics is fiction, but that argument itself would be fiction, and therefore one would be left with a fictional metaphysics of fiction.

\section{Introduction}

The theme or title of my paper on the programme is Metaphysics, imagination and innovation in the humanities.

I would love to present a metaphysics of the imagination or a metaphysics of poiesis, in the sense that many poets have attempted. Poets, who have formed a world out of an insistence of the Real, or an insistence of unformed matter. Poets, who have given shape and form to raw life, or naked life, stratifying by identifying such naked life, or stratifying by identifying the body without organs (see Deleuze \& Guattari 2009:11). Other poets have created matter and form from nothing, ex-nihilo, like it is believed the Abrahamic God did when He created the world. Yet, in another tradition, God is believed to have created physics, the physical world, from chaos: formless matter. There are all these different traditions as to what poets create, but what unites poets is the idea that poets create and therefore they are often perceived to be close to the divine, maybe even seen as exemplary images (imago Dei) of the creator God, as creators of worlds and meaning. Poets create either from chaos or from the void, or from the desert, and in their creation, they create both the physics and the metaphysics of the poem (see Badiou 2014).

Jewish-Greek-Arabic poets created worlds from formless chaotic matter or the void or the desert, which is the meta of their physics. However, this leaves us with a new question: what is the meta of metaphysics? Which poem has captured the meta, not of physics, but of metaphysics? Or do we, perhaps, need a physics of metaphysics? A physics of metaphysics to understand the movement, appearance and behaviour of the matter of meta in metaphysics? But could such physics of metaphysics be a physics without its own metaphysics, its own time and space, then becoming a metaphysics of metaphysics - a meta-metaphysics? Would this not be the search of the last poem, or maybe the first and final poem, the absolute sovereign poem: the poem that speaks the language of truth - the poem that is truth?

Let us not play with words or in words, in the time-play-space, Zeit-Spiel-Raum (Caputo 1993:30) of language, as time is too precious and so is this space.

Let us do the serious physics of this metaphysics by taking the time and the space of this conference seriously. The space, the location of this conference is Africa, and the time, is a time where there is a powerful call for decolonial thinking, and maybe this theme, The resurgence of metaphysics in science, philosophy and theology, ${ }_{1}^{1}$ is a play, or rather playroom of privilege - the privilege of the white man, contemplating the poets, philosophers and theologians of Europe and the Arab world? White physics and white metaphysics? Or as Derrida (1974:11) calls it 'white mythology'.

1.It was a conference held by the South African Science and Religion Forum at UNiSA from 23 to 24 March 2017 
But then again, let us not be politically distracted from the attraction of this topic. The calling of these themes, the calling of this matter, which has called us to this time place, is a calling and like all callings that gather, it is a political and/or religious calling. The call that gathers into a time-space is a political call, and it is the logos of that world that in calling gathers all together into its world. A logos that can be seen as the religion or the ideological-political sovereign of that specific world, which gathers and binds (religare) all the bodies into its language, the language of that particular timeplay-space: that particular metaphysics, which gives time and space to all the matter, all the bodies, the onta- of that particular ontology.

The world is created in the silent speaking of language (Heidegger 1971), as it is created in the poetry of language. I would personally be inclined to follow this imaginative route and celebrate the beauty and the power of poetry, the Word that creates, as in the book of Genesis. But sadly, that inclination would be problematic, as the Word that creates only makes sense within the time-space of a particular story (fiction) told in a book, a sacred book for some, but a book all the same, the book of Genesis, which is ascribed to a fictional author, Moses, the implied author of the five books of Moses.

With these introductory musings, I have outlined my fiction, with its metaphors and poetry, whose traces I will follow in the rest of this article.

\section{Physics and metaphysics}

Physics is the study of matter in its motion and behaviour in time and space. The question, how to study matter in time and space, is an ancient question pondered already by Plato and Aristotle, and therefore this question, together with its various answers, ushered in what some have called Western thought, or the reason of the white man.

How to study matter, the physical world, for some the empirical world, or the natural world? Aristotle, as interpreted by Ricoeur, offers one possibility for the study of this matter, namely via the dual process of mimesis and muthos (Ricoeur 1984:31ff.), where muthos is the organisation of the events (Ricoeur 1984:33), but understood in the active sense of 'organising the events into a system, so as to mark the operative character of all the concepts in the Poetics' (Ricoeur 1984:33). Poetics therefore is understood as the art of composing plots: the organisation of events into a time sequence, for example. Likewise, with mimesis, which can be translated as 'imitation' or 'representation'. However, what needs to be transmitted in these translations is the mimetic activity, 'the active process of imitating or representing something' (Ricoeur 1984:33), and more specifically the imitation and representation of action (Ricoeur 1984:33).

Mimesis is understood as imitating or representing, as a mimetic activity in as much as it produces something, namely the organisation of events into a plot, which is muthos (Ricoeur 1984:34). Mimesis and muthos thus cannot be clearly separated, but interact or transverse each other in the creation of meaning, in the creation of understanding through narrative.

Thus, muthos and mimesis work together to create understanding and meaning via a plot, a narrative plot, as it is in narrative that muthos can organise mimetic events into a plot. For Ricoeur, understanding and meaning is created through narrative. 'To make up a plot is already to make the intelligible spring from the accidental, the universal from the singular, the necessary or the probably from the episodic' (Ricoeur 1984:41). To create a plot is to create a theory, to create a concept and to create a paradigm through the organisation of mimetic events. For example, the movement and behaviour of matter mimicked and represented is organised into a plot, a paradigm or a theory, where these mimetic events are placed into time and space - a certain muthos.

This is how one makes sense, creates meaning and understanding, of matter and the movement and behaviour of matter, but what is the relationship between matter and mimesis [language] and thought (thought-system or muthos)?

\section{Poetry, language and thought}

Poetry, language and thought is not my original subtitle, but the title of a book written by Heidegger, translated as such by Hofstadter (1971), although I will not be exploring Heidegger in these first paragraphs, but rather Derrida, or more accurately Derrida's interpretation of Aristotle.

The question of poetry, or let me rather say, the question of metaphor, 'is at the heart of those very general questions concerning the relations of language, thought, and reality' (Derrida 1974:5). If the question of poetry is at the heart of those general questions, then it seems that the question of poetics and the question of metaphysics are related, or they are even the same question. The question of metaphor and philosophy are intimately related, more so than it is possible to think, nor is it possible to separate the one from the other in thought. Philosophy can think metaphor, but can it think metaphor without metaphor? Or is metaphor the thinking of philosophy?

Polyphilos, from Anatole France's The Garden of Epicurus, speaking to Aristos, argues that:

any expression of an abstract idea can only be an analogy. By an odd fate, the very metaphysicians who think to escape the world of appearances are constrained to live perpetually in allegory. A sorry lot of poets, they dim the colors of the ancient fables, and are themselves but gatherers of fables. They produce white mythology. ${ }^{2}$ (Derrida 1974:11)

Philosophy cannot escape metaphor, metaphysics cannot escape metaphor, and even this sentence is worked by metaphor. Is the word 'escape' not a metaphor?

2.What is metaphysics? A white mythology that assembles and reflects western culture: the white man takes his own mythology (i.e. Indo-European mythology), his culture: the white man takes his own mythology (i.e. Indo-European mythology), his
logos - that is, the mythos of his idiom, for the universal form of that which it is still logos - that is, the mythos of his idiom, for the universal
his inescapable desire to call Reason (Derrida 1974:11). 
- Why is that so?

- Why is the 'prison' of metaphor so complete, that nothing can escape its power or hold?

- To answer that question, one would need to seek to understand, via a metaphor, which would not be thought as such, the relation between language, thought and reality.

\section{Language, thought and reality}

The relationship between these three has troubled philosophy, metaphysics in particular, but also science and religion in the past, and will continue to do so in the present and the future.

If one had clarity on either one of these three terms, it might make things easier. What is reality or matter, maybe even naked matter or naked life? What is thought? And how are these two related to each other? Is language the mediation? Is language how matter comes to mind, comes to thought, via the process of mimesis and muthos?

Is language the mediation of how matter, physis is revealed, becomes present, comes to be at hand? What is it that gives the physis? Is it physis itself, or is it something in humanity, a human characteristic? What is the metaphysics of physics? That which gives, places matter in time and space?

From the very beginning, since Plato and Aristotle, right through to Hegel and even still today, this has been the question of philosophy. In most of this tradition, language is seen as some form of mediator, or as the medium linking thought and matter.

What is the relationship between matter (physis), thought (dianoia) and language (lexis)?

If language is the link, the mediator, how truthful, accurate and trustworthy is this link? How natural is it? Or is it unnatural? Is it a construction? Is it a perfect fit? Jacques Lacan (Verhaeghe 1995) argued that language always fails, it is a failed link and therefore we continue talking.

It is because of this imperfection that language (narrative) is tragic, prone to misunderstanding and misrepresentation. ${ }^{3}$

It is a tragedy that the link between lexis and dianoia is never a direct link or a perfect link, but imperfect. If a speaker's thoughts were directly manifested without the mediation of words, there would be no tragedy. We exist and act in tragedy only on the condition that we speak (see Derrida 1974:32).

Lexis exists, and metaphor with it, to the extent that thought is not manifested directly of itself. Stated differently, lexis [metaphor] exists because the sense of thought is not a phenomenon in itself. ${ }^{4}$

3.If there were no difference between dianoia and lexis, there would be no room for tragedy (Derrida 1974:32).

4.Metaphor exists only to the extent that someone is supposed to be manifesting by an utterance such-and-such a thought which remains in itself unobvious, hidden or an utterance such-and-such a thought which remains in itself unobvious, hidden or
latent. Thought happens upon metaphor, or metaphor is the lot of thought at the moment at which a sense attempts to emerge of itself to say itself, to express itself, moment at which a sense attempts to emerge of itself to say
to bring itself into the light of language (Derrida 1974:32).
However, the theory of metaphor remains a theory of sense and supposes a certain naturalness in this figure - the lumens naturale - where nature is believed to be the active part and makes a gift of itself, but even if it does, or if it would, it does so in metaphor ${ }^{5}$ (mimesis). The idea that Nature makes a gift of itself is a metaphor.

If one would forget the metaphor for a moment, one could ask: How would such a gift be possible? A gift always has a giver and a receiver, so who gives and who receives? Does matter give itself to be revealed and in that sense, determines the revelation - the basis for materialism? Or does humanity give the form, the ideal in which matter is cast, or grasped, and only through the form and cast has meaning - idealism? Or are these two alternatives not opposites, but rather the same - two metaphors, the one casting and grasping, the other giving and revealing? Whatever happens, it happens in metaphor.

The link between physis and lexis is metaphor, or mimesis. It happens in metaphor, but that it happens in metaphor is forgotten.

In metaphor, matter is presented, imitated, represented, made present by the activity of mimesis, either as giving, revealing or grasping and casting, and this is taken or received as true. It is taken as a matter of fact, on the basis of a belief that imitation, the representation, or the presentation is accurate, and that it correlates with reality, and because of this correlation, it is therefore truthful.

That the link, the mediator, is truthful and therefore trustworthy, is vitally important for humanity. Truth as aletheia is that which is unveiled, unconcealed and believed to be truly the matter, or the matter of fact.

This requirement links metaphor (mimesis) to truth: 'What makes metaphor possible (what makes good and true metaphor possible) is what makes truth possible' (Derrida 1974:37).

One could make peace with metaphor as long as there is believed to be some natural link, that metaphor, mimesis is part of nature. At times, mimesis can be read as something that seems to be inherent in physis, in other words, it is part of the nature of things to reveal themselves.

As physis is revealed through mimesis, it must be believed that mimesis naturally belongs to physis. It is one of physis' natural characteristics, as physis includes its own exteriorisation and its double (see Derrida 1974:37). This means that mimesis is a natural movement, but of what? Is it the natural movement of matter or the natural movement of logos, which is the natural movement of human reason, thinking and understanding?

Mimesis belongs to logos and therefore, in Aristotle, it is a special characteristic of humans as it is natural to humans.

5.Like mimesis, metaphor comes back to physis, to its truth and its presence. Nature always finds in it its own analogy, its own resemblance to itself, and finds increas there only of itself. In metaphor nature makes gift of herself' (Derrida 1974:45). 
For Aristotle, it is what defines the human animal, namely the ability to imitate and thereby to create meaning. Animals and plants can mimic or ape, but they cannot create meaning through mimesis. In this sense, only humans are worldcreating, as Heidegger would later argue and animals are poor in world, whilst plants and stones are without world. ${ }^{6}$

Aristotle argues that mimesis is a natural movement, the natural movement of the logos of humanity, as mimesis is the proper (natural or essential) property of humanity. For Aristotle, only humanity imitates:

He alone takes pleasure in imitating, learns to imitate and learns by imitation. The power of truth, as an unveiling of nature (physis) by mimesis, is a congenital property of man as a physical being. (Derrida 1974:37-38)

The naturalness of mimesis (metaphor or poetry) has two sources, but not as presumed one being a characteristic of physis, but both sources are 'natural' characteristics of humanity. The natural origin of poetry (metaphor), the two sources, are both part of human nature according to Aristotle (see Derrida 1974:38). It is natural for humanity to imitate, as humanity learns by imitation, and secondly, it is natural for humanity to delight in works of imitation.

These two causes or sources confirm that logos, mimesis and aletheia become one and the same possibility. How does one ensure that mimesis is true knowledge? Aristotle argues that true knowledge is only where logos is at home in the phonè (see Derrida 1974:38). The voice is the best organ for imitation. Thus, the natural link is found in the voice, which naturally imitates nature and thus binds mimesis, logos and aletheia together.

Thus, metaphor, an effect of mimesis and homoiosis, and a manifestation of analogy, will be a means of knowledge: a subordinate, but for all that a certain means of knowledge. We may say of it what is said of poetry: it is more philosophical and more serious than history, as it not only tells something particular, but also expresses what is general, probably, and necessary (Derrida 1974:38).

Yet, poetry has always had this ancillary status:

for metaphor, properly controlled, is in the service of truth, but the master cannot be content with it, and must prefer that form of discourse which shows truth in its fullness. (Derrida 1974:38)

What cannot be avoided is that metaphor is mimesis trying its chance, but it is always mimesis at risk. The ideal of any language, and of metaphor in particular:

is to allow the thing itself to be known, a turn of speech or of thought will be better the closer it brings us to its essential or proper truth. (Derrida 1974:48)

This is the space of language, a space that is opened up by the differences between essence, the 'proper' and the accident.

\footnotetext{
6.'The stone has no world', he says, der Stein ist weltlos, 'The animal is poor in world', das Tier is weltarm, 'Man is world-configuring or world-forming', der Mensch is weltbildend [Heidegger 1983: 261ff.] (Derrida 2011:6).
}

Hegel, whom Derrida once described as the last philosopher of the book and the first philosopher of writing (Derrida 1997:26), in his The Philosophy of Fine Arts, also takes on the idea of metaphor. He argues that the role of metaphor (the role of language) is more natural as it is linked to the sensuous experience of matter (see Derrida 1974:24).

A word, in the first instance, designates something entirely sensuous (nur etwas ganz sinnliches bedeutet). This sensuous designation (meaning) is then carried over (übertragen) into a spiritual sphere (Geistiges). Hegel uses the example of grasping something or to comprehend something, in German fassen or begreifen. The sensuous meaning of grasping something with one's hand is clear, yet this sensuous meaning is carried over into the intellectual (Geistiges) sphere of understanding and grasping a concept or a theory, where the sensual meaning of the hand grasping an apple is totally forgotten. For Hegel, the metaphorical aspect is forgotten through general use, and through this general use, an expression that is not strictly accurate (uneigentlich) becomes what is eigentlich, and the metaphorical aspect is forgotten.

The metaphorical aspect of much of language is forgotten. Even in the language of science, metaphors are forgotten, in the sense that one forgets that they are metaphors and treats them as 'matters of fact'. For example, in biology, one speaks of cells, where one does not think of a prison or a monastery, but of a beehive. This metaphor has forgotten that it is a metaphor and is understood as a concept or matter of fact. Are not all concepts metaphors (see Derrida 1974:66)?

It is only after Nietzsche, and more even so with Heidegger, that the role of language shifted from mediator to the meta of metaphysics, and language became the house of being. Language, the creator of worlds and no longer just the mediator or the link.

It is language, or more specifically, difference (Austrag) that gathers world and things into a simple onefold ${ }^{7}$ (Heidegger 1971:207).

It is in this peal of stillness that humans dwell. It is language that carries out the world in which humans dwell. It is this world, carried out via the difference between thing and world, where things gestate world and world grants things their place (see Heidegger 1971:202-203). Things, the onta of ontology, carry out a world via the process of mimesis and muthos. Yet, it is this world, ontology (see also Badiou 2009:39) that grants these things their place, it is the muthos in which things (matter's movement and behaviour) become visible and make sense.

7.When the difference gathers world and things into the simple onefold of the pain of intimacy, it bids the two to come into their very nature. The difference is the intimacy, it bids the two to come into their very nature. The difference is the command out of which every bidding itself is first called, so that each may follow the command. The command of the difference has ever already gathered all bidding within itself. The calling, gathered together within itself, which gathers to itself in the calling, is the pealing as the peal. The calling of the difference is the double stilling. The gathered bidding, the command, in the form of which the difference calls world and things, is the peal of stillness. Language speaks in that the command of the difference calls world and things into the simple onefold of their intimacy. Language speaks as the peal of stillness (Heidegger 1971:207). 
Mythology is therefore figuration proper. Such is its secret, and the secret of its myth - of its truth - for the whole of Western consciousness. To be figuration proper, to be the proper figuration of the proper, is to realise properly - improperlyproperly, as a supplement to propriety - the proper itself. Nature with all its 'powers' would never attain to its truth without the double process of natural and figurative 'theogony', effective and represented in consciousness, presenting itself, uttering itself in its mythos (Nancy 1991:54).

\section{Meta-poetics, meta-metaphor and meta-metaphysics}

Philosophy, as the philosophy Aristotle, Ricoeur, Heidegger and Derrida have, can offer various theses, theories and interpretations of metaphor. Yet, that theory, thesis or interpretation will always be a philosophical discourse 'the whole surface of which is worked by metaphor' (Derrida 1974:31). Therefore, it is not so much that metaphor is in the text of philosophy, but rather that texts of philosophy are in metaphor (see Derrida 1974:60).

Can we ignore the sleep of philosophy? Can one ignore the forgetfulness of philosophy ${ }^{8}$ ?

What name must be given to all these tropes that have structured all these philosophical oppositions that were believed to be fundamental or structuring or originating? The meta-structuring concepts, theories, paradigms or ideas? Yet, each of these theories, concepts remain metaphors. Would one therefore need to find a metaphor of metaphor? Or in Bachelard's view, a meta-poetics (Derrida 1974:29)?

...it consists in the thought of a poetico-fictioning ontology, an ontology presented in the figure of an ontogeny where being engenders itself by figuring itself, by giving itself the proper image of its own essence and the self-representation of its presence and its present (Nancy 1991:54).

What would be necessary is a poetics of philosophy?

It is impossible to get a grip on metaphor, to get a grip on poetics, as the only tool to get a grip (begreifen) is via the dual process of mimesis and muthos, in other words: metaphor. The only tool that one has with which to understand metaphor and poetics is metaphor and poetics, and the result is a circular argument. ${ }^{9}$

In other words, philosophy cannot solve the problem of metaphor, or stated differently, metaphysics cannot solve the question of metaphysics:

8.Philosophy, like the scientist: (1) can only discover what he has put in or, at least what as a philosopher he thinks he has put in. (2) the setting up of the fundamental oppositions of 'metaphrology' (physis/technè, physis/nomos, sensible/intelligible space/time, signifier/signified, etc.) took place through the history of a metaphorical language, or rather though movements of tropes which, for all that they can no longer be called by the philosophical name of metaphor, do not however constitute, and for the same reason, 'proper' language (Derrida 1974:28).

9.On the one hand, it is impossible to get a grip on philosophical metaphor as such from the outside, because one is using a concept of metaphor that remains a product of philouts. philosophy. Only philosophy itseff would seen to have any authority over its metaphoricalproductions. But, on the other hand, and for the same reason, philosophy deprives itself of what it gives. As its instruments belong to its field of study, it is powerless to exercise control over its general topology and metaphorics. Indeed, they can only be perceived around a blind spot or a deaf point (Derrida 1974:28)
Wallace Stevens in one of his poems writes,

Thus the theory of description matters most

It is the theory of the word, for those

For whom the word is the making of the world. (quoted in Badiou 2014:8)

It is the theory of description, mimesis and metaphor that matters most, but that theory is only another description:

In sum, fictioning is the subject of being. Mimesis is the poiesis of the world as true world of gods, of men and of nature. The myth of myth is in no way an ontological fiction; it is nothing other than an ontology of fiction or representation: it is therefore a particularly fulfilled and fulling form of ontology of subjectivity in general. (Nancy 1991:55)

It is for this reason that Laruelle (2013a:xvi) turns to science - a science of philosophy, or rather a science of metaphysics, a physics of metaphysics, where one treats all the elements of philosophy and science as metaphors. In his science of philosophy, he treats all the concepts, theories and paradigms as material, as the physics, the physical matter under investigation. Yet, Laruelle (2012:103-104) does not attempt to create an opposition between science and philosophy or accuse science of not thinking, as Heidegger did. Nor does he want to prove Heidegger or Ricoeur or Derrida wrong. He does not want to replace their theories, their philosophy with a better philosophy, nor does he want to challenge the 'discoveries' or constructions of science, nor does he want to challenge philosophy with science, or physics, or mathematics. He wants to use all these theories, systems, concepts and philosophies as his material.

\section{Fictional metaphysics of fiction}

Laruelle wants to think philosophy, but not philosophically, because to think philosophy philosophically would only be to remain in the circular thought of metaphor. He proposes to think philosophy scientifically, not a science of philosophy, but to use philosophy as the material, as the physis of his science. What is necessary is to emplot philosophy and science, with all their theories, concepts and paradigms - not into a muthos of what is real or what the world actually is, but into a muthos of what philosophy, the sciences, knowledge and thinking is.

He does this not in an attempt to think the final philosophy. He is not in search of the final answer of the relationship between language-thought and reality, but to offer a democracy of thought, a democracy of philosophies (Laruelle 2013b:Kindle pos 4970 of 7408), where all philosophies are seen as equally necessary, but insufficient.

How does Laruelle do this? He does this by not seeing thought (language) and reality as a duel, but by dualysing the force-(of)-thought via an immanent clone (see Laruelle 2013b:Kindle pos 4717 of 7408). In other words, both reality and thought, the reality of thought and the thought of reality, are determined in the last instance by the Real, which remains foreclosed to thought and thus to reality.

The Real is not given, but determines in the last instant, whilst remaining radically yet not absolutely foreclosed to 
thought. The duel of form-matter has been replaced in nonphilosophy as it involves the identity-of-the-last-instance and the unilateral duality for form and for matter (Laruelle 2013b:Kindle pos 4741 of 7408).

Form and matter are both 'given', determined in the last instance as a unilateral duality by the Real, where the relationship between form and matter is determined by various contingents, but insufficient yet necessary philosophical or scientific decisions.

The different philosophies are seen as different yet equally contingent philo-fictions (see Laruelle 2012:280).

This leaves one with various fictions, metaphysical fictions or various metaphors. Any attempt to escape these metaphors, would only be via a new metaphor. Has Laruelle helped? Or is his non-philosophy still just another metaphor? Are forceof-thought, unilateral-duality, determined-in-the-last-instance not also metaphors? Yes, indeed they are, but not metaphors of form and/or matter, but metaphors for metaphors, and in that sense a meta-metaphysics, which says nothing about physics or metaphysics, but much about the different metaphysical theories, world views and viewing them all as necessary, but insufficient. He is not offering the final God's eye view from which to judge, but from within the force-(of)thought. Yet, is Laruelle's thought not also an attempt at the final explanation of humanity's predicament?

And what about the question of white mythology? Is this imperialism of metaphor, not a white man's imperialism? This universalism of metaphor - is it not white man's reason? Is this not the highest form of imperialism, to decide what reason is, to decide what the world is, to decide what is proper to humanity? A universalism of the Western abstract machine, from which there is no escape. Everything is captured between the double pincers of the lobster $\operatorname{God}^{10}$ of white man's reason. Badiou describes this double bind as democratic materialism, the bind of language and bodies, where there is nothing but languages and bodies (Badiou 2009:4), controlled by white man's reason, the abstract machine of the West.

The call to politics - the call of religion - the eternal sun:

With every metaphor, there is no doubt somewhere a sun; but each time that there is a sun, metaphor has begun. If the sun is already and always metaphorical, it is not completely natural. (Derrida 1974:53)

With every language, there is a muthos, there is a world, there is Being, there is a philosophical decision and thus a philo-fiction. These philo-fictions are necessary and believed to be sufficient, as they explain all. In that sense, they can be compared to religion or politics as explanations of the ultimate reality.

There is religion and there is politics which calls a particular world together, a logos of that particular world which gives

10.God is a Lobster, or a double pincer, a double bind. Not only do strata come at leas in pairs, but in a different way, each stratum is double (it itself has several layers) (Deleuze \& Guattari 2011:40). each and everything, everybody, in that particular world its ontological place. For Heidegger, this was determined in each epoch by the sendings of Being, the epochs of Being and therefore the challenge for him was, to think the happening or the place of these epochs: the Ereignis. The Ereignis is that which grants the space and time of the metaphysical or ontological epochs their play - Zeit-Spiel-Raum (Caputo 1993:30). Each of these epochs had their own sun, their own muthos, their own onto-theology bringing time and space into play. Indeed, these fictions are always political as they link bodies to language. There are numerous different languages and with each language, each fiction and each metaphor, there will be different bodies and different hierarchies of bodies. The language (logos) determines the ontology of a particular world, as the language, logos, determines the logic of that particular world: the ontology. There is no escaping, this white priviledge, this white mythology, as any attempt at escape would only again be captured by reason. A new identity (revolutionary subject) might becreated and with it revolutionary political communities, but the reason, the logic of the abstract machine of the West, will capture these revolutionary political communities and include them into the ever expanding rhizome. The abstract machine is created by the two sign regimes, which includes the regime of flight into the desert (see Deleuze \& Guattari 2011:111ff.), and therefore the abstract machine will always include the lines of flight through its apparatus of capture (Deleuze \& Guattari 2011:424) and therefore the imperialism of the rhizome grows.

Badiou argues that there are not only these philo-fictions, languages and bodies in democratic materialism, but there is also truth (see Badiou 2009:4). One could argue that there is not only a lobster God, but also truth. Truth, as Badiou argues, advances in these different worlds suspended, like the poet's conscience, between the void and the pure event (Badiou 2009:4). Truth for Badiou is neither a supplement to language and bodies nor is it a synthesis where truth is seen as the selfrevelation of bodies seized by languages. Truths exist as exceptions to what there is. These ideas Badiou develops into what he calls a materialist dialectic, which is a critique of every critique (Badiou 2009:8) and specifically a critique of democratic materialism. Badiou is not content with a democracy of philofictions, which he calls democratic materialism, and thus adds to these philo-fictions the idea of truth. Truth that is revealed universally through subjects, faithful subjects (see Badiou 2009:9). Yet, these faithful subjects need to be without community and without individuation (Badiou 2009:9) as they cannot belong to any ontology, because they are exceptions to the logos of these ontologies. They are not part of any fiction world (language-body), and therefore cannot be part of a community nor do they have a particular individuation within a particular language-body, but are outside these languagebodies, maybe even victims of these language-bodies, challenging the language-body. Yet, even as victims, they cannot be victims who can be identified, or victims who can be bound together into revolutionary communities, but they need to be generic victims without identity or community, or faithful subjects, faithful only to the event of truth.

There are languages (philo-fictions) and bodies, democratic materialism, and there is truth. The truth of the victims of 
these language-bodies and the poets, subjects faithful to these truth events, caught between the desert of metaphors and the pure event, to speak that which language cannot say.

Only poets speak the unspeakable in, from and out of the pure event, the Ereignis, the speaking of language, the pain of language, the wound of language, speaking from, in and out of difference (Austrag), speaking in and from différance, the tragedy of metaphor, speaking from and in the desert of metaphors, or the desertification of language. Speaking from the cracks, from the victims of democratic materialism, speaking from the crack in the double pincer of the lobster God. They speak from there their prophetic words, challenging the worlds that are, and speaking new worlds into existence. Only poets can say the unsayable, speak the unspeakable and thereby usher in a new metaphor, a new world. A new world with its scientists, philosophers and priests.

Only poets can speak the decolonial worlds, freed from the confines of colonial imperialist language-bodies. Out of the cracks, the tragedy of the victims of white man's metaphors, decolonial worlds emerge, but only to be colonised again by the scientists with their body of knowledges, the philosophers with their metaphysics and the priests with their religion and their sacred books.

But the poets are not silenced as the pain of language insists, the wounds cannot be healed. Or as Nancy argues that a name has been given to this voice of interruption: literature ${ }^{11}$ (Nancy 1991:63) - the fictional metaphysics of fiction.

11.Is literature then not just another myth? Yet, indeed it is, but it is different: '..' literature's revelation, unlike myth's, does not reveal a completed reality, nor the reality of a completion. It does not reveal, in a general way, some thing - it reveals rather the unrevealable: namely, that it is itself, as a work that reveals and gives access to a vision and to the communion of a vision, essentially interrupted. In the work, there is a share of myth and a share of literature or writing. The latter interrupts the former, it 'reveals' precisely through its interruption of the myth (through the incompletion of the story or the narrative) - and what literature or writing reveals is above all else its interruption, and it is in this respect that it can be called, if it still can be - and it no longer can be - a "mythic invention"”' (Nancy 1991:63).

\section{Acknowledgements Competing interests}

The author declares that he has no financial or personal relationships which may have inappropriately influenced him in writing this article.

\section{References}

Badiou, A., 2009, Logics of worlds: Being and event, 2, transl. A. Toscano, Continuum, London.

Badiou, A., 2014, The age of poets: And other writings on twentieth-century poetry and prose, transl. B. Bosteels, Verso, London.

Caputo, J.D., 1993, Demythologizing Heidegger, Indiana University Press, Indianapolis, IN.

Deleuze, G. \& Guattari, F., 2009, Anti-Oedipus: Capitalism and schizophrenia, transl. R. Hurley, M. Seem and H.R. Lane, Penguin Books, London.

Deleuze, G. \& Guattari, F., 2011, Thousand plateaus: Capitalism and schizophrenia, transl. B. Massumi, University of Minnesota Press, Minneapolis, MN.

Derrida, J., 1974, 'White mythology: Metaphor in the text of philosophy', transl. F.C.T. Moor, New Literary History 6(1), 5-74. https://doi.org/10.2307/ 468341

Derrida, J., 1997, Of grammatology, transl. G.C. Spivak, John Hopkins Press, Baltimore, MD.

Derrida, J., 2011, The Beast \& the sovereign, volume II, transl. G. Bennington, University of Chicago Press, Chicago, IL.

Heidegger, M., 1971, Poetry, language, thought, transl. A. Hofstadter, Harper Perennial Modern Classics, New York.

Heidegger, M., 1983, Die Grundbegriffe der Metaphyisik: Welt - Endlichkeit Einsamkeit, Freiburger Vorlesung Wintersemester 1999/30, H. von FriedrichWilhelm von Herrmann, Vitorio Klosterman, Frankfurt am Main.

Laruelle, F., 2012, From decision to heresy: Experiments in non-standard thought, R. Mackay (ed.), Sequence Press, New York.

Laruelle, F., 2013a. Anti-Badiou: On the introduction of maoims into philosophy, transl. R. Mackay, Bloomsbury, London.

Laruelle, F., 2013b, Principles of non-philosophy, transl. N. Rubczak \& A.P. Smith, Bloomsbury, London, Kindle version.

Nancy, J-L., 1991, The inoperative community, transl. P. Connor, L. Garbus, M. Holland \& S. Sawhney, University of Minnesota Press, Minneapolis, MN.

Ricoeur, P., 1984, Time and narrative volume 1, transl. K. McLaughlin \& D. Pellauer, University of Chicago Press, Chicago, IL.

Verhaeghe, P., 1995, 'From impossibility to inability: Lacan's theory on the four discourses', The Letter: Lacanian Perspectives on Psychoanalysis 3(Spring), 91-108. 